\title{
Postoperative Nausea and Vomiting in Paediatric Anaesthesia
}

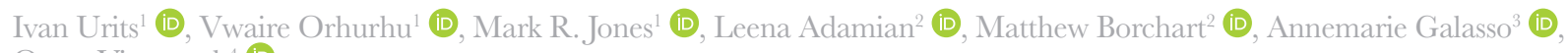 \\ Omar Viswanath ${ }^{4}$ (D) \\ ${ }^{1}$ Beth Israel Deaconess Medical Center, Department of Anesthesia, Critical Care, and Pain Medicine, Harvard Medical School, Boston, MA, USA \\ ${ }^{2}$ Creighton University School of Medicine - Phoenix Regional Campus, Phoenix, AZ, USA \\ ${ }^{3}$ Georgetown University School of Medicine, Washington, DC, USA \\ ${ }^{4}$ Valley Anesthesiology and Pain Consultants, Phoenix, AZ; University of Arizona College of Medicine Phoenix, Department of Anesthesiology, Phoenix, AZ; \\ Creighton University School of Medicine, Department of Anesthesiology, Omaha, NE, USA
}

Cite this article as: Urits I, Orhurhu V, Jones MR, Adamian L, Borchart M, Galasso A, et al. Postoperative Nausea and Vomiting in Paediatric Anaesthesia. Turk J Anaesthesiol Reanim 2020; 48(2): 88-95.

\begin{abstract}
Postoperative nausea and vomiting (PONV) is a common complication in paediatric anaesthesia and is a source of significant morbidity. Various independent risk factors have been implicated in the development of paediatric PONV, including higher pain scores postoperatively, the use of opioids for pain management and the use of volatile anaesthetics for the maintenance of anaesthesia. This review of the current literature regarding the prevention and treatment of paediatric PONV is based on a search of the PubMed database, which identified published clinical trials, systematic reviews and meta-analyses. While the occurrence of PONV in many cases is difficult to avoid entirely, the risk can be mitigated by the use of multimodal nonopioid analgesic regimens, total intravenous drugs in favour of volatile anaesthetics and an appropriate regimen of prophylactic pharmacotherapy. Frequently administered drug classes for the prevention of PONV include corticosteroids, 5HT3 antagonists and anticholinergics. The clinical use of the findings in the literature may help to reduce the occurrence of PONV in children. In this review, we provide comprehensive and updated information on the risk factors contributing the occurrence of PONV in children, outline the current opinion on the drugs that are commonly used for management and provide an overview of the guidelines that are used to help establish the prophylaxis and treatment of paediatric PONV.
\end{abstract}

Keywords: Anaesthesia, guidelines for prophylaxis and treatment, postoperative nausea and vomiting, risk factors

\section{Introduction}

Postoperative nausea and vomiting (PONV) is a common complication in the paediatric population and is a source of significant morbidity. The incidence of PONV in children is alarmingly high, as it is estimated to be between $33.2 \%$ to $82 \%$ depending on patient risk factors (1). PONV typically describes nausea, vomiting, or retching that can occur starting in the post-anaesthesia care unit (PACU) and continuing through the 24 hours following surgery. Post-discharge nausea and vomiting includes symptoms that persist for up to 7 days after anaesthesia. PONV occurs twice as often in children than in adults and can lead to longer PACU stays, delays in hospital discharge and subsequent unplanned readmissions, which ultimately lead to significant financial burden on the patients (2). The syndrome of nausea, vomiting and dehydration is one of the leading causes of paediatric readmissions, accounting for $51.2 \%$ of such cases. Moreover, paediatric readmission, within one week of discharge, is estimated to contribute to $\$ 1$ billion in healthcare costs annually (3).

A variety of antiemetic regimens are recommended for the prevention and treatment of PONV in children, including pharmacotherapy with dexamethasone, 5HT-3 receptor antagonists, butyrophenones, prokinetics, anticholinergics and antihistamines. In this review, we provide an update of the current understanding in the management of paediatric PONV. 


\section{Risk factors}

Various independent risk factors have been implicated in the development of paediatric PONV. In a multi-centre study of 1257 children, the following major risk factors were identified: a duration of surgery 30 minutes or longer, age 3 years or older, strabismus surgery and a history of PONV in the child or immediate relatives (parents or siblings) (4). Moreover, the risk of developing PONV was stratified and estimated to be $9 \%, 10 \%, 30 \%, 55 \%$ and $70 \%$ depending on the presence of $0,1,2,3$, or 4 risk factors respectively (Table 1). The duration of surgery is believed to contribute to the incidence of PONV because of longer exposure to emetogenic stimuli. Higher incidence of PONV is also associated with higher pain scores postoperatively, the use of opioids for pain management and the use of volatile anaesthetics for maintenance of anaesthesia (2). Age under 3 years seems to be protective against developing PONV, though the mechanism is poorly understood as the contrary holds true in adults whose age is less than 50 years (5). The female gender increases the risk for PONV, though this has not been shown to be clinically significant and is not considered to be a major contributory factor. It is further believed that there is a degree of genetic contribution to the development of PONV that resulted in the observed familial association, though the exact nature of this has not been described (4).

\section{Emetogenic procedures}

Various surgeries are associated with a higher risk of developing PONV; some of the highest incidences occur in ocular and ENT surgeries including tonsillectomy, adenoidectomy,and strabismus correction (6). One study found that PONV rates were as high as $82 \%$ in paediatric patients undergoing tonsillectomy and another reported PONV rates of $54 \%$ in children undergoing strabismus surgery (7). Rates of PONV have also been reported to be greater than

\section{Main Points:}

- Postoperative nausea and vomiting typically describes nausea, vomiting, or retching that can occur starting in the post-anaesthesia care unit (PACU) and continuing through the 24 hours following surgery.

- Postoperative nausea and vomiting leads to significant morbidity and healthcare costs, indicating the need for appropriate management.

- A variety of antiemetic regimens are recommended for the prevention and treatment of PONV in children, including pharmacotherapy with dexamethasone, 5HT-3 receptor antagonists, butyrophenones, prokinetics, anticholinergics and antihistamines.

- The use of predictive risk scores to identify patients at increased risk of PONV is useful to determine the appropriate and cost-effective course of therapy while providing the greatest patient benefit, reducing the length of hospital stay and reducing the frequency of unplanned admissions.
$50 \%$ in orchidopexy and hernia repair (6). Considering these high rates of PONV, antiemetic prophylaxis should especially be considered in patients undergoing these procedures.

\section{Influence of the choice of the anaesthetic drug}

Given the high prevalence of PONV in paediatric patients, it is important for clinicians to be cognisant of strategies to minimise the risk of PONV in their patients. One such strategy is to avoid using volatile anaesthetics in favour of total intravenous anaesthesia (TIVA) with propofol during the intraoperative period. This change alone reduces the rate of PONV by as much as $25 \%$ (8). When the use of inhaled anaesthetics cannot be avoided, one study recommends single-drug antiemetic prophylaxis, which was found to be equally effective as TIVA in preventing PONV after strabismus surgery in children (9). Regional anaesthesia is also preferred over general anaesthesia to reduce the risk of PONV. Studies have shown that using local anaesthesia instead of or in addition to general anaesthesia reduces the incidence of PONV in tonsillectomies (10).

Increased opioid use has been found to increase the risk of PONV in a dose-dependent manner (11). Non-opioid multimodal pain management is favoured for acute intraoperative and postoperative pain control in the operating room and on the medical floor after PACU discharge. It has been shown that using caudal blocks for regional anaesthesia in patients undergoing renal, bladder, or ureteral procedures reduced PONV and was associated with lower use of opioids and rescue anti-emetics (12). NSAIDs are additionally effective as part of a multimodal regimen that has been shown to be effective in managing postoperative pain. Moreover, their use can lead to fewer cases of PONV (13). Once thought that the use of NSAIDs may increase the risk of bleeding, in a study of patients undergoing tonsillectomy and adenoidectomy procedures, no increased incidence of bleeding was associated with the use of NSAIDs (13). Additionally, the use

Table 1. Risk factors for the occurrence of PONV

\begin{tabular}{|c|c|}
\hline \multirow[t]{3}{*}{ Surgical } & Duration greater than 30 minutes \\
\hline & Ocular surgery \\
\hline & ENT surgery (adenoidectomy, tonsillectomy) \\
\hline \multirow[t]{3}{*}{ Anaesthetic } & Use of volatile anaesthetic \\
\hline & Use of opioids \\
\hline & Increased postoperative pain \\
\hline \multirow[t]{4}{*}{ Patient } & Age of $>3$ years \\
\hline & History or immediate family history \\
\hline & Prolonged preoperative fast \\
\hline & State of dehydration \\
\hline
\end{tabular}

PONV: postoperative nausea and vomiting 
of nitrous oxide has also been associated with PONV and is recommended to be avoided in patients at an increased risk for developing PONV (8).

\section{Preoperative optimisation}

Another factor that may influence the incidence of PONV is preoperative fasting. The purpose of preoperative fasting is to reduce the volume of gastric contents during the procedure and thus lower risk of aspiration, which can lead to infection and acute respiratory distress syndrome. Prolonged preoperative fasting, however, has been associated with postoperative nausea (14). One study investigated the effects of a shorter preoperative fasting time and failed to find a significant difference in the reduction of PONV, but it did find that a shorter fasting period was associated with lesser postoperative pain following tonsillectomy procedures (14). It is important to note that if this reduction in pain results in less use of opioids to control pain, there may be a subsequent decrease in PONV.

Carbohydrate loading, i.e. the preoperative intake of a carbohydrate-rich fluid, has also been suggested as a method to reduce PONV. A randomised controlled trial found that carbohydrate loading resulted in fewer instances of postoperative nausea and suggested that there may also be a subsequent reduction of vomiting in these patients (15). It was suggested that preoperative carbohydrates may prevent the body from persisting in a prolonged catabolic state throughout surgery, possibly reducing inflammation, pain and resultant nausea/ vomiting.

Hydration is yet another important factor in the development of PONV in paediatric patients. In a study of 150 children undergoing lower abdominal and penile surgery, liberal intraoperative fluid therapy resulted in significantly lower rates of PONV (16). They suggest that supplemental perioperative fluid helps to correct the existing fluid deficits that may have been caused by fasting, thereby helping to maintain adequate intravascular fluid volume, which prevents the activation of mechanisms that may otherwise trigger nausea and vomiting.

\section{Pharmacologic Management (Table 2)}

\section{Dexamethasone}

Dexamethasone is a synthetically derived corticosteroid that is commonly administered for the prevention of PONV. Its mechanism of action in preventing PONV is not fully understood, but it is thought that the agonism of glucocorticoid receptors found within the bilateral solitary tract nucleus and area postrema of the brainstem prevent activation of the chemoreceptor trigger zone, implicated as a central emetogenic mediator (8). Another theory centres around the anti-inflammatory properties of dexamethasone, which may help to reduce local inflammatory reactions caused by surgery and that otherwise leads to parasympathetically driven stimulation of the chemoreceptor trigger zone (17). Dexamethasone is typically dosed at $150 \mu \mathrm{g} \mathrm{kg}^{-1}$ up to a total administered dose of 5 $\mathrm{mg}$ in children, though total doses as high as $8 \mathrm{mg}$ have been demonstrated to be safe (17). Maximum anti-emetogenic efficacy is likely attained when administered at or prior to induction as dexamethasone achieves its peak effect approximately 2 hours after injection (17).

The success of dexamethasone in reducing PONV alone when compared with a placebo has resulted in its increased use in both paediatric and adult populations. There is a cumulative effect when it is given in combination with other therapies (18). The rate of PONV when dexamethasone was given in combination with a super-hydration therapy using lactated ringer solution was $5 \%$, as compared to $35 \%$ when dexamethasone was administered as a monotherapy agent (19). Similarly, a combination of dexamethasone and ondansetron was shown to significantly reduce PONV rates in the first 3 hours postoperatively as compared to either group alone (20). Another study compared the rates of PONV in patients who received a dexamethasone-dimenhydrinate combination versus a dexamethasone-ondansetron combination and found that the dexamethasone-dimenhydrinate combination was more effective (21).

Despite its regular use and effectiveness in reducing PONV, there are several potential post-operative complications associated with the use of dexamethasone. These include increased risk of post-tonsillectomy bleeding, perioperative hyperglycaemia, increased postoperative infection risk and cancer recurrence (8). Though historically, dexamethasone use has been associated with increased post-tonsillectomy bleeding risk in children, the findings by Yiu et al. (22) and Mahant et al. (23) bring this association into question. Dexamethasone is a potent steroid and as such, a single dose can induce insulin resistance in the whole body and can alter cardiac glucose metabolism, which may potentially result in hyperglycaemia (24). Another commonly listed complication of dexamethasone for use with PONV is a risk of cancer recurrence due to perioperative immune impairment, however, studies by Colin and Gan (25) and Chanimov et al. (26) have failed to find any such correlation. Lastly, tumour lysis syndrome is listed as a possible complication and is associated with rapid onset of hyperphosphatemia, hyperkalaemia, lactic acidosis, acute renal failure and hyperuricaemia. The proposed mechanism associated with steroid induced tumour lysis syndrome is the induction of growth arrest and apoptosis in lymphocytes (26).

\section{HT3 Antagonists}

Three commonly used 5-HT3 antagonists are ondansetron, granisetron and dolasetron. They have a shared mechanism of action and function by acting on both the peripheral and cen- 
Table 2. Summary of commonly used perioperative antiemetics in paediatric anaesthesia

\begin{tabular}{|c|c|c|c|}
\hline Drug class & Mechanism of action & Adverse effects & Dose and time of administration \\
\hline \multicolumn{4}{|l|}{ Corticosteroid } \\
\hline - Dexamethasone & $\begin{array}{l}\text { Poorly understood: thought to act } \\
\text { on glucocorticoid receptors } \\
\text { May centre around the ability of } \\
\text { dexamethasone to reduce local } \\
\text { inflammatory reactions after surgery. }\end{array}$ & $\begin{array}{l}\text { Increased risk of post-tonsillectomy } \\
\text { bleeding, tumour lysis syndrome, } \\
\text { perioperative hyperglycaemia, } \\
\text { increased postoperative infection } \\
\text { risk and cancer recurrence. }\end{array}$ & $\begin{array}{l}150 \mu \mathrm{g} \mathrm{kg} \mathrm{kg}^{-1} \text { up to } 8 \mathrm{mg} \text {. } \\
\text { Administer drug immediately before } \\
\text { or after induction of anaesthesia } \\
\text { instead of after surgery. }\end{array}$ \\
\hline \multicolumn{4}{|l|}{ 5-HT3 Antagonist } \\
\hline $\begin{array}{l}\text { - Ondansetron } \\
\text { - Granisetron } \\
\text { - Dolasetron }\end{array}$ & $\begin{array}{l}\text { Antagonising the action of serotonin } \\
\text { in the } 5 \text { HT } 3 \text { receptor-rich areas of } \\
\text { the brain }\end{array}$ & $\begin{array}{l}\text { Headache, dizziness, elevated liver } \\
\text { enzymes, constipation, diarrhoea, } \\
\text { arrhythmias and QT prolongation }\end{array}$ & $\begin{array}{l}\text { Ondansetron: } \\
\text { - } 100 \mu \mathrm{g} \mathrm{kg}^{-1} \text { or max } 4 \mathrm{mg} \mathrm{IV} \\
-8 \mathrm{mg} \text { oral } \\
\text { - administer at end of surgery } \\
\text { Granisetron: } \\
\left.\text { - } 0.35 \text { to } 3 \mathrm{mg} \mathrm{IV}(5-20 \mu \mathrm{g} \mathrm{kg})^{-1}\right) \\
\text { - administer at end of surgery } \\
\text { Dolasetron: } \\
\text { - } 12.5 \mathrm{mg} \text { IV at end of surgery or at } \\
\text { time of induction }\end{array}$ \\
\hline \multicolumn{4}{|l|}{ Butyrophenone } \\
\hline - Droperidol & $\begin{array}{l}\text { Potent centrally acting D2 receptor } \\
\text { antagonist }\end{array}$ & $\begin{array}{l}\text { Drowsiness, sedation, headaches } \\
\text { Rare: EPS }\end{array}$ & $\begin{array}{l}50 \mu \mathrm{g} \mathrm{kg}^{-1} ; 30 \text { minutes before the end } \\
\text { of surgery }\end{array}$ \\
\hline $\begin{array}{l}\text { Prokinetics } \\
\text { - Metoclopramide }\end{array}$ & $\begin{array}{l}\text { Peripheral and central (basal ganglia) } \\
\text { DA receptor antagonist }\end{array}$ & $\begin{array}{l}\text { EPS (akathisia, dystonia, } \\
\text { Parkinsonism and dyskinesia), } \\
\text { sedation, diarrhoea } \\
\text { Rare: Apnoea, anaphylaxis, } \\
\text { respiratory distress or arrest, NMS, } \\
\text { TD. Galactorrhoea. } \\
\text { Gynaecomastia, urinary retention, } \\
\text { priapism (*all resolved with } \\
\text { treatment/ discontinuation) }\end{array}$ & $\begin{array}{l}\text { Single dose: } 0.1 \text { to } 0.5 \mathrm{mg} \mathrm{kg}^{-1} \\
\text { intravenously } \\
\text { Multiple dose: } * \text { No PONV-specific } \\
\text { data, but CINV: } 1.15 \mathrm{mg} \mathrm{kg}^{-1} \text { day }^{-1} \\
\text { intravenously or orally to } 12 \mathrm{mg} \mathrm{kg}^{-1} \\
\text { day }^{-1} \text { intravenously }\end{array}$ \\
\hline \multicolumn{4}{|l|}{ Anticholinergics } \\
\hline - Scopolamine & $\begin{array}{l}\text { Competitive smooth muscle } \\
\text { muscarinic antagonist } \\
\text { Percutaneous absorption, detected } \\
\text { in plasma within } 4 \text { hrs of patch } \\
\text { application }\end{array}$ & $\begin{array}{l}\text { Sedation, dry mouth, vision } \\
\text { changes, decreased gastric motility } \\
\text { and delayed gastric emptying } \\
\text { Caution with other anticholinergics } \\
\text { (antihistamine, TCA, muscle } \\
\text { relaxant) }\end{array}$ & $0.25-0.75 \mathrm{mg}$ via a transdermal patch \\
\hline \multicolumn{4}{|l|}{ Antihistamines } \\
\hline $\begin{array}{l}\text { - Dimenhydrinate } \\
\text { - Hydroxyzine }\end{array}$ & $\begin{array}{l}\text { Reversible } \mathrm{H} 1 \text { receptor inhibition } \\
\text { More commonly used for } \\
\text { motion sickness }\end{array}$ & $\begin{array}{l}\text { Sedation, CYP } 450 \text { inhibitor, dry } \\
\text { mouth, constipation } \\
\text { Less common: confusion, blurry } \\
\text { vision, urine retention }\end{array}$ & $\begin{array}{l}0.5 \mathrm{mg} \mathrm{kg}^{-1} \text {, up to } 25 \mathrm{mg} \text { (rectal) } \\
2 \mathrm{mg} \mathrm{kg}^{-1} \text { day }^{-1} \text { PO } \\
1.1 \mathrm{mg} \mathrm{kg}^{-1} \mathrm{IM}\end{array}$ \\
\hline
\end{tabular}

tral nervous system. Enterochromaffin cells in the gut release 5 -HT in response to gastric irritation or cellular damage and 5-HT binds to 5 - $\mathrm{HT}_{3}$ receptors on vagal afferents in the gastric mucosa, which project to the vomiting centre (28). 5-HT3 antagonists act by inhibiting the action of serotonin in $5-\mathrm{HT}_{3}$ receptor-rich areas of the brain, thus alleviating emesis (28).

Dosing varies between these three drugs. Dosing for ondansetron is $100 \mu \mathrm{g} \mathrm{kg} \mathrm{kg}^{-1}$ or a maximum of $4 \mathrm{mg}$ IV or $8 \mathrm{mg}$ oral and works best when administered at the end of surgery (8). Gran- isetron also functions best when given at the end of surgery and its dosing ranges from $0.35-3 \mathrm{mg}$ IV (5-20 $\left.\mu \mathrm{g} \mathrm{kg} \mathrm{kg}^{-1}\right)(8)$. Dolasetron is the only $5-\mathrm{HT}_{3}$ receptor that has been shown to be effective either at the end of surgery or at induction; its dosing is typically $12.5 \mathrm{mg}$ IV (8).

Ondansetron, granisetron and dolasetron have all been found to be more effective than placebos in reducing PONV (29). Ondansetron and granisetron in combination with other drugs used for PONV have been found to be more 
effective than either alone (8). Compared to $4 \mathrm{mg}$ IV ondansetron and $1 \mathrm{mg}$ PO granisetron, the incidence of PONV and the requirement for rescue anti-emetics were not statistically different (30). Despite this, the cost to achieve similar effects was approximately $\$ 26$ form ondansetron and $\$ 47$ for granisetron, indicating that ondansetron is more cost-effective (30). Interestingly, a Birmingham et al. (31) found no significant difference in PONV within the first 12 hours post-operatively, but in the subsequent 12 hours, $40 \mu \mathrm{g} \mathrm{kg}^{-1}$ granisetron had shown significantly lower rates of PONV than $100 \mu \mathrm{gg}^{-1}$ of ondansetron IV, suggesting that granisetron may be a better option for long-term PONV control. The difference in results may be attributed to a difference in the dose of medication administered. Comparisons of ondansetron and dolasetron have no significant difference in the rates of PONV between the two drugs, but dolasetron has been found to be more cost effective than ondansetron (29). When compared to traditional anti-emetics such as anticholinergics, antihistamines, butyrophenones and benzamides, 5-HT3 antagonists are significantly more effective for PONV (32).

The commonly listed side effects of 5-HT3 antagonists include headache, dizziness, elevated liver enzymes, constipation, diarrhoea, arrhythmias and QT prolongation (8). Studies investigating the effects of granisetron and ondansetron on QT prolongation have found that granisetron significantly reduces the heart rate and prolongs the QT interval as compared to ondansetron $(33,34)$. However, a meta-analysis comparing rates of QT prolongation and other arrhythmias with the use of various 5-HT3 antagonists alone and in combination with other anti-emetics found a minimal statistical difference between the groups. The only significant finding was that dolasetron plus dexamethasone when compared to ondansetron plus dexamethasone prolonged the QTc (35). The clinical consequences of these QT prolongations in practice are negligible (36).

\section{Butyrophenones}

Droperidol is a potent, centrally acting dopamine receptor antagonist with known antiemetic properties in adults (37). Although given as a low-dose prophylactic medication, its known adverse effects include sedation, drowsiness, headaches and extrapyramidal symptoms (EPS) (38). Bourdaud et al. (39) found that low-dose droperidol given near the end of surgery did not decrease the incidence of POV when added to a two-drug combination of ondansetron and dexamethasone, rather, it significantly increased the incidence of drowsiness and headache. An additional study found no significant decrease in POV when given in combination with dexamethasone at recommended paediatric doses (40). Due to its adverse effect profile and no increase in efficacy, droperidol remains largely unused in the paediatric population, limited to refrac- tory emesis in an inpatient setting (39). Low-dose prophylactic haloperidol also has known anti-emetic properties in adults, although its use has not extended to children to date.

\section{Prokinetics}

The prokinetic metoclopramide is a peripheral and central-acting dopamine receptor antagonist with antiemetic properties. Although it is used in adults, it carries a 'black box' warning for tardive dyskinesia and has subsequently declined in popularity in younger paediatric patients and remains an alternative to the use of corticosteroids and serotonin receptor antagonists (41). Currently, Canadian and EU drug regulatory agencies contraindicate its use in children younger than 1 year of age and caution against its use in children younger than 5 years (38). The British National Formulary for Children (BNFG) also restricts metoclopramide use in patients younger than 20 years of age to cases of severe intractable vomiting of a known cause, vomiting associated with radiotherapy and cytotoxins, as an aid to gastro-intestinal intubation, a prokinetic in neonates and as a pre-medication for diagnostic procedures (39). A meta-analysis of metoclopramide use in 2699 children identified common adverse effects, in accordance with doses given (42). In studies administering multiple doses, the most common side effects were extrapyramidal symptoms, sedation and diarrhoea. When given as a single dose, the primary adverse effect was sedation. Adverse effects that were life threatening or slow to resolve were rare. Thus, it is recommended to limit its use to refractory or severe cases of emesis and care should be taken to teach parents to recognise its signs and symptoms to minimise alarm.

\section{Anti-Cholinergics}

Scopolamine is a competitive muscarinic antagonist with anti-nausea and antiemetic properties and is often used as adjunctive therapy (43). Its transdermal delivery produces a low-dose and steady plasma concentration, minimising adverse effects such as sedation, dry mouth, vision changes, dizziness, decreased gastric motility and delayed gastric emptying. Although widely used in adults for PONV, few studies have examined the use of scopolamine in children; however, the BNFC recommends the use of a quarter of a patch from the ages of 1 month to 3 years and a half of a patch from ages 3-10 years (44).

\section{Anti-histamines}

Dimenhydrinate is a reversible $\mathrm{Hl}$ receptor inhibitor with antiemetic properties (45). Adverse effects in the paediatric population include increased sedation and longer observation time in the PACU, with no difference in time to arousal and hospital discharge (46). Although dose estimation remains unclear, it is worth considering as an inexpensive antiemetic. Further studies are needed to determine the safety and efficacy of dimenhydrinate in the paediatric population (45). 


\section{Treatment and prevention}

PONV remains a significant adverse effect for patients receiving general anaesthesia, particularly for paediatric patients. Several risk score models exist for adults, although many of these scores are not applicable in children (37). The use of predictive risk scores to identify patients at increased risk of PONV is useful to determine the appropriate and cost-effective course of therapy while providing the greatest patient benefit, reducing the length of hospital stay and reducing the frequency of unplanned admissions (47).

To guide paediatric PONV prophylaxis, Bourdaud et al. (7) created a risk-predictive scoring model for vomiting in the

\section{Table 3. Vomiting in the postoperative period (VPOP)} scoring system

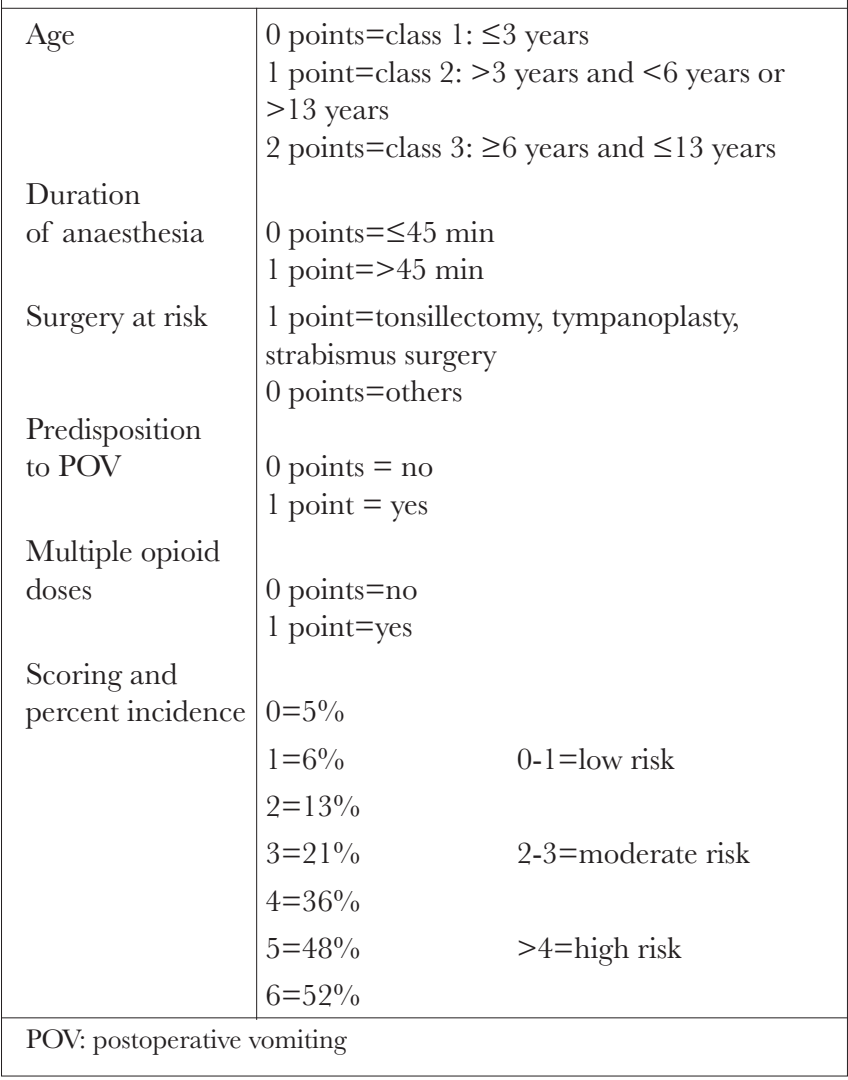

Table 4. Consensus guidelines for the management of PONV

Multimodal PONV Dexamethasone plus sub hypnotic prophylaxis therapy Propofol dose $\left(1 \mathrm{mg} \mathrm{kg}^{-1}\right.$ bolus followed provides optimal outcomes by infusion at $\left.20 \mathrm{mcg} \mathrm{kg}^{-1} \mathrm{~min}^{-1}\right)$

5-HT3 antagonist $\left(0.05 \mathrm{mg} \mathrm{kg}^{-1}\right)$ plus dexamethasone $\left(0.015 \mathrm{mg} \mathrm{kg}^{-1}\right)$ [most effective]

5-HT3 antagonist $\left(0.1 \mathrm{mg} \mathrm{kg}^{-1}\right)$ plus Droperidol $\left(0.015 \mathrm{mg} \mathrm{kg}^{-1}\right)$ postoperative period (VPOP). The calculated score identifies five independent risk factors for vomiting in children and stratifies these to indicate risk severity (Table 3 ). These factors include age, duration of anaesthesia, surgery at risk, a predisposition to POV and multiple opioid doses. The scores range from $0-6$, with 6 representing children at the highest risk. An additional guideline published by the Society for Ambulatory Anaesthesia (SAMBA) described a scoring system ranging from 0-4, with a point given for family history of POV, surgery duration greater than 30 minutes, age greater than 3 years and strabismus surgery (48).

In the face of low compliance, Gan et al. (8) cites multiple studies supporting the efficacy of multimodal prophylactic pharmacologic therapy to reduce the baseline risk for PONV (Table 4). These findings highlight the additive nature of different drug classes in preventing and treating PONV. A combination of most 5- $\mathrm{HT}_{3}$ antagonists with dexamethasone offers effective emesis risk reduction and is supported for use in children (49). Although the combination of dexamethasone and sub hypnotic propofol, or the combination of a 5- $\mathrm{HT}_{3}$ antagonist with droperidol had equal efficacy, neither were recommended as first-line treatment options in children due to the adverse effects of droperidol and the painful delivery of propofol (8). One article proposed the use of monotherapy for small surgeries or minimal PONV predictive risk and multimodal prophylaxis in patients with moderate to high risk (50). Use of dimenhydrinate, droperidol and metoclopramide should be reserved for rescue therapy.

In addition to optimising perioperative pharmacologic treatment, it is beneficial to minimise risk factors for nausea and vomiting preoperatively. To this end, the use of regional anaesthesia as an adjunct to general anaesthesia can limit the amount of post-operative opioid use, thereby reducing opioid-associated PONV. To further reduce the risk, volatile anaesthetics and nitrous oxide can be used in favour of intravenous propofol (9).

\section{Conclusions and Summary}

The incidence of postoperative nausea and vomiting (PONV) in paediatric patients remains high, particularly after emetogenic procedures and in individuals with an increased level of risk factors. It is a frequent source of discomfort during postoperative recovery both after PACU discharge on the medical floors and also at home after undergoing a surgical procedure. PONV leads to significant morbidity and healthcare costs, indicating the need for appropriate management. While certain anaesthetic techniques can minimise emetogenic effects, it is imperative that paediatric clinicians be cognisant of specific risk factors that their patients may have that increase the likelihood of PONV manifestation. The

PONV: postoperative nausea and vomiting 
use of multimodal prophylactic antiemetic medication provides an effective alternative and adjunct for patients who are at a risk of PONV. A systematic review of the current literature supports the efficacy of several prophylactic pharmacological agents, many of which have shown minimal incidence of severe adverse effects when they are selected appropriately. Further, guidelines based on risk factor assessment can provide a predictive score to guide adequate prevention strategies, PONV treatment and a reduction in the baseline risk of PONV occurrence.

Peer-review: Externally peer-reviewed.

Author Contributions: Concept - I.U., O.V.; Design - I.U.; Supervision - O.V., I.U.; Resources - O.V.; Materials - O.V.; Data Collection and/or Processing - M.R.J., V.O.; Analysis and/or Interpretation - M.R.J., V.O., L.A., M.B.; Literature Search - L.A., M.B., A.G.; Writing Manuscript - I.U., M.R.J., V.O., O.V., L.A., A.G., M.B.; Critical Review - I.U., O.V.

Conflict of Interest: The authors have no conflicts of interest to declare.

Financial Disclosure: The authors declared that this study has received no financial support.

\section{References}

1. Eberhart LHJ, Morin AM, Guber D, Kretz FJ, Schäuffelen A, Treiber H, et al. Applicability of risk scores for postoperative nausea and vomiting in adults to paediatric patients. Br J Anaesth 2004; 93: 386-92. [CrossRef]

2. Edler AA, Mariano ER, Golianu B, Kuan C, Pentcheva K. An analysis of factors influencing postanesthesia recovery after pediatric ambulatory tonsillectomy and adenoidectomy. Anesth Analg 2007; 104: 784-9. [CrossRef]

3. Brown EG, Anderson JE, Burgess D, Bold RJ, Farmer DL. Pediatric surgical readmissions: Are they truly preventable? J Pediatr Surg 2017; 52: 161-5. [GrossRef]

4. Eberhart LHJ, Geldner G, Kranke P, Morin AM, Schäuffelen A, Treiber H, et al. The Development and Validation of a Risk Score to Predict the Probability of Postoperative Vomiting in Pediatric Patients. Anesth Analg 2004; 99: 1630-7. [CrossRef]

5. Apfel CG, Philip BK, Cakmakkaya OS, Shilling A, Shi YY, Leslie JB, et al. Who is at risk for postdischarge nausea and vomiting after ambulatory surgery? Anesthesiology 2012; 117: 47586. [CrossRef]

6. Minai F, Shafiq F, Rehman A. Audit of postoperative nausea and vomiting in paediatric day case surgery. J Pak Med Assoc 2011; 61: 273-6.

7. Bourdaud N, Devys JM, Bientz J, Lejus C, Hebrard A, Tirel O, et al. Development and validation of a risk score to predict the probability of postoperative vomiting in pediatric patients: the VPOP score. Paediatr Anaesth 2014; 24: 945-52. [CrossRef]

8. Gan TJJ, Diemunsch P, Habib ASSS, Kovac A, Kranke P, Meyer TAAA, et al. Consensus Guidelines for the Management of
Postoperative Nausea and Vomiting. Anesth Analg 2014; 118 : 85-113. [GrossRef]

9. Schaefer MS, Kranke P, Weibel S, Kreysing R, Ochel J, Kienbaum $\mathrm{P}$. Total intravenous anesthesia vs single pharmacological prophylaxis to prevent postoperative vomiting in children: A systematic review and meta-analysis. Pediatr Anesth 2017; 27: 1202-9. [CrossRef]

10. Naja Z, Kanawati S, Al Khatib R, Ziade F, Naja ZZ, Naja AS, et al. The effect of IV dexamethasone versus local anesthetic infiltration technique in postoperative nausea and vomiting after tonsillectomy in children: A randomized double-blind clinical trial. Int J Pediatr Otorhinolaryngol 2017; 92: 21-6. [CrossRef]

11. Roberts GW, Bekker TB, Carlsen HH, Moffatt CH, Slattery PJ, McClure F. Postoperative nausea and vomiting are strongly influenced by postoperative opioid use in dose-related a manner. Anesth Analg 2005; 101: 1343-8. [GrossRef]

12. Faasse MA, Lindgren BW, Frainey BT, Marcus CR, Szczodry DM, Glaser AP, et al. Perioperative effects of caudal and transversus abdominis plane (TAP) blocks for children undergoing urologic robot-assisted laparoscopic surgery. J Pediatr Urol 2015; 11: 121.e1-121.e7. [CrossRef]

13. Dorkham MC, Chalkiadis GA, Von Ungern Sternberg BS, Davidson AJ. Effective postoperative pain management in children after ambulatory surgery, with a focus on tonsillectomy: Barriers and possible solutions. Paediatr Anaesth 2014; 24: 239-48. [CrossRef]

14. Klemetti S, Kinnunen I, Suominen T, Antila H, Vahlberg T, Grenman R, et al. The effect of preoperative fasting on postoperative pain, nausea and vomiting in pediatric ambulatory tonsillectomy. Int J Pediatr Otorhinolaryngol 2009; 73: 263-73. [CrossRef]

15. Tudor-Drobjewski BA, Marhofer P, Kimberger O, Huber WD, Roth G, Triffterer L. Randomised controlled trial comparing preoperative carbohydrate loading with standard fasting in paediatric anaesthesia. Br J Anaesth 2018; 121: 656-61. [CrossRef]

16. Ashok V, Bala I, Bharti N, Jain D, Samujh R. Effects of intraoperative liberal fluid therapy on postoperative nausea and vomiting in children-A randomized controlled trial. Paediatr Anaesth 2017; 27: 810-5. [GrossRef]

17. Ho CM, Wu HL, Ho ST, Wang JJ. Dexamethasone prevents postoperative nausea and vomiting: Benefit versus risk. Acta Anaesthesiol Taiwanica 2011; 49: 100-4. [CrossRef]

18. Awad K, Ahmed H, Abushouk AI, Al Nahrawi S, Elsherbeny MY, Mustafa SM, et al. Dexamethasone combined with other antiemetics versus single antiemetics for prevention of postoperative nausea and vomiting after laparoscopic cholecystectomy: An updated systematic review and meta-analysis. Int J Surg 2016; 36: 152-63. [GrossRef]

19. Sayed JA, F. Riad MA, M. Ali MO. Comparison of dexamethasone or intravenous fluids or combination of both on postoperative nausea, vomiting and pain in pediatric strabismus surgery. J Clin Anesth 2016; 34: 136-42. [GrossRef]

20. Thomas R, Jones N. Prospective randomized, double-blind comparative study of dexamethasone, ondansetron, and ondansetron plus dexamethasone as prophylactic antiemetic therapy in patients undergoing day-case gynaecological surgery. Br J Anaesth 2001; 87: 588-92. [CrossRef] 
21. Kizilcik N, Bilgen S, Menda F, Türe H, Aydın B, Kaspar EC, et al. Comparison of Dexamethasone-Dimenhydrinate and Dexamethasone-Ondansetron in Prevention of Nausea and Vomiting in Postoperative Patients. Aesthetic Plast Surg 2017; 41: 204-10. [GrossRef]

22. Yiu Y, Mahida JB, Cooper JN, Elsey NM, Deans KJ, Minneci $\mathrm{PC}$, et al. The effect of perioperative dexamethasone dosing on post-tonsillectomy hemorrhage risk. Int J Pediatr Otorhinolaryngol 2017; 98: 19-24. [GrossRef]

23. Mahant S, Keren R, Localio R, Luan X, Song L, Shah SS, et al. Dexamethasone and Risk of Bleeding in Children Undergoing Tonsillectomy. Otolaryngol Neck Surg 2014; 150: 872-9. [CrossRef]

24. Qi D, Pulinilkunnil T, An D, Ghosh S, Abrahani A, Pospisilik JA, et al. Single-dose dexamethasone induces whole-body insulin resistance and alters both cardiac fatty acid and carbohydrate metabolism. Diabetes 2004; 53: 1790-7. [GrossRef]

25. Colin B, Gan TJ. Cancer Recurrence and Hyperglycemia with Dexamethasone for Postoperative Nausea and Vomiting Prophylaxis. Anesth Analg 2014; 118: 1154-6. [CrossRef]

26. Chanimov M, Koren-Michowitz M, Cohen ML, Pilipodi S, Bahar M. Tumor lysis syndrome induced by dexamethasone. Anesthesiology 2006; 105: 633-4. [CrossRef]

27. Bartlett R, Hartle AJ. Routine use of dexamethasone for postoperative nausea and vomiting: the case against. Anaesthesia 2013; 68: 892-6. [GrossRef]

28. Thompson AJ, Lummis SCR. The 5-HT3 receptor as a therapeutic target. Expert Opin Ther Targets 2007; 11: 527-40. [CrossRef]

29. Paech MJ, Rucklidge MWM, Banks SL, Gurrin LC, Orlikowski CEP, Pavy TJG. The efficacy and cost-effectiveness of prophylactic 5-hydroxytryptamine3 receptor antagonists: tropisetron, ondansetron and dolasetron. Anaesth Intensive Care 2003; 31 : 11-7. [CrossRef]

30. White PF, TangJ, Hamza MA, Ogunnaike B, Lo M, Wender RH, et al. The Use of Oral Granisetron Versus Intravenous Ondansetron for Antiemetic Prophylaxis in Patients Undergoing Laparoscopic Surgery: The Effect on Emetic Symptoms and Quality of Recovery. Anesth Analg 2006; 102: 1387-93. [CrossRef]

31. Birmingham SD, Mecklenburg BW, Lujan E, Dacanay RG, Boyle PK, Green R. Dolasetron versus ondansetron as single-agent prophylaxis for patients at increased risk for postoperative nausea and vomiting: a prospective, double-blind, randomized trial. Mil Med 2006; 171: 913-6. [CrossRef]

32. Fujii Y. The utility of antiemetics in the prevention and treatment of postoperative nausea and vomiting in patients scheduled for laparoscopic cholecystectomy. Curr Pharm Des 2005; 11: 3173-83. [CrossRef]

33. Pinarli FG, Elli M, Dagdemir A, Baysal K, Acar S. Electrocardiographic findings after 5-HT3 receptor antagonists and chemotherapy in children with cancer. Pediatr Blood Cancer 2006; 47: 567-71. [GrossRef]

34. Buyukavci M, Olgun H, Ceviz N. The effects of ondansetron and granisetron on electrocardiography in children receiving chemotherapy for acute leukemia. Am J Clin Oncol 2005; 28 : 201-4. [CrossRef]

35. Tricco AC, Blondal E, Veroniki AA, Soobiah C, Vafaei A, Ivory $\mathrm{J}$, et al. Comparative safety and effectiveness of serotonin receptor antagonists in patients undergoing chemotherapy: a systematic review and network meta-analysis. BMC Med 2016; 14: 216. [CrossRef]

36. Keefe DL. The cardiotoxic potential of the 5-HT(3) receptor antagonist antiemetics: is there cause for concern? Oncologist 2002; 7: 65-72. [GrossRef]

37. Apfel CC, Korttila K, Abdalla M, Kerger H, Turan A, Vedder I, et al. A Factorial Trial of Six Interventions for the Prevention of Postoperative Nausea and Vomiting. N Engl J Med 2004; 350: 2441-51. [GrossRef]

38. Henzi I, Sonderegger J, Tramèr MR. Efficacy, dose-response, and adverse effects of droperidol for prevention of postoperative nausea and vomiting. Can J Anesth Can d'anesthésie 2000; 47: 537-51. [CrossRef]

39. Bourdaud N, François C, Jacqmarcq O, Guye ML, Jean J, Studer $\mathrm{C}$, et al. Addition of droperidol to prophylactic ondansetron and dexamethasone in children at high risk for postoperative vomiting. A randomized, controlled, double-blind study. Br J Anaesth 2017; 118: 918-23. [CrossRef]

40. Flubacher P, Fournier N, Cherpillod J, Waridel F, Nydegger $\mathrm{M}$, Albrecht E. A randomised controlled trial of placebo, droperidol or ondansetron to prevent nausea and vomiting after tonsillectomy in children receiving dexamethasone. Anaesthesia 2017; 72: 859-63. [CrossRef]

41. Mt-Isa S, Tomlin S, Sutcliffe A, Underwood M, Williamson P, Croft NM, et al. Prokinetics Prescribing in Paediatrics. J Pediatr Gastroenterol Nutr 2015; 60: 508-14. [GrossRef]

42. Lau Moon Lin M, Robinson PD, Flank J, Sung L, Dupuis LL. The Safety of Metoclopramide in Children: A Systematic Review and Meta-Analysis. Drug Saf 2016; 39: 675-87. [CrossRef]

43. Apfel CC, Zhang K, George E, Shi S, Jalota L, Hornuss C, et al. Transdermal scopolamine for the prevention of postoperative nausea and vomiting: A systematic review and meta-analysis. Clin Ther 2010; 32: 1987-2002. [GrossRef]

44. Spinks A, Wasiak J. Scopolamine (hyoscine) for preventing and treating motion sickness. Cochrane Database Syst Rev 2011: CD002851. [GrossRef]

45. Enarson P, Gouin S, Goldman RD. Dimenhydrinate use for children with vomiting. Can Fam Physician 2011; 57: 431-2.

46. Kranke P, Diemunsch P. The 2014 consensus guidelines for the management of postoperative nausea and vomiting A leapfrog towards a postoperative nausea and vomiting-free hospital. Eur J Anaesthesiol 2014; 31: 651-3. [CrossRef]

47. Blacoe DA, Cunning E, Bell G. Paediatric day-case surgery: an audit of unplanned hospital admission Royal Hospital for Sick Children, Glasgow. Anaesthesia 2008; 63: 610-5. [GrossRef]

48. Hooper VD. SAMBA Consensus Guidelines for the Management of Postoperative Nausea and Vomiting: An Executive Summary for Perianesthesia Nurses. 2015; [CrossRef]

49. Gan TJ, Sinha AC, Kovac AL, Jones RK, Cohen SA, Battikha JP, et al. A Randomized, Double-Blind, Multicenter Trial Comparing Transdermal Scopolamine Plus Ondansetron to Ondansetron Alone for the Prevention of Postoperative Nausea and Vomiting in the Outpatient Setting. Anesth Analg 2009; 108: 1498-504. [CrossRef]

50. Höhne C. Postoperative nausea and vomiting in pediatric anesthesia. Curr Opin Anaesthesiol 2014; 27: 303-8. [CrossRef] 